\title{
MEDICINE AND PHARMACY IN BRITISH POLITICAL PRINTS-THE EXAMPLE OF LORD SIDMOUTH
}

\author{
by \\ WILLIAM H. HELFAND*
}

The British have been the masters of political caricature. At least until the accession of Queen Victoria, a succession of masters of the art flourished, including William Hogarth, James Gillray, Thomas Rowlandson, and the three Cruikshanks. The French, until the Revolution of 1789 , produced little, for little was permitted unless it was directed at an enemy country. The Americans did not really begin to show what they could accomplish until the administration of Andrew Jackson in the 1830s. A French eyewitness of events in London between 1771 and 1784 suggested that one of the privileges of the nation was the liberty to produce satires which held up to ridicule enemies of the day. While the French would produce songs and the Dutch strike medals, he added, the British would engrave prints, the most significant being satires. ${ }^{1}$

The inventiveness of British caricaturists took many forms, but always there was the need to visualize a point of view on an often complex political issue. Because the illustration had to be instantly grasped, artists frequently made use of an experience or an event with which the reader could identify quickly. Thus, medical subjects are fairly widespread in political caricatures with the physician, pharmacist, dentist, and nurse, as well as others in the field of medical care, frequently being shown. Certain metaphors associated with medical themes were used repeatedly in Britain, and common themes appear also in American, French, and Italian caricatures. For example, the idea of the nation, symbolized in this case by John Bull, being advised by his doctors, most often ministers in power at the time, has been widely employed. In Great Britain alone, in the period before 1830, there are more than forty such caricatures, many of more than routine interest. In these prints, John Bull is the puzzled, frightened, or angry victim, being bled, given cathartics and enemas, phrenologized, prescribed medicines, and, in short, treated with every acceptable

*William H. Helfand, Merck Sharp \& Dohme Intl., Rahway, New Jersey 07065, USA.

A modified version of this paper was presented to the Society of Apothecaries of London (Gideon de Laune Lecture, April 1984). Those prints noted in the text with BM numbers are those listed in the Britsih Museum catalogue (F.G. Stevens (editor), Catalogue of prints and drawings in the British Museum, Div. 1: Political and personal satires, vols. 1-4, London, 1870-83; and M. Dorothy George (editor), Catalogue of political and personal satires preserved in the Department of Prints and Drawings in the British Museum, vols. 5-11, London, 1935-54. Those without such numbers are in the author's collection.

\footnotetext{
${ }^{1}$ Mary Dorothy George, English political caricature to 1792, 2 vols., vol. 1, Oxford, Clarendon Press, 1959, p. 13.
} 


\section{W. H. Helfand}

medical procedure of the day. ${ }^{2}$

The doctor administering his gilded pill (BM 9849, plate 1), is only one of the many examples that could be cited using this common theme. The subject of the print, the recently created and to this day controversial income tax, shows John Bull resisting the offerings of the doctor and commenting that "the pill tho gilded remains a pill still". The doctor in this case is Henry Addington, the Prime Minister, who had inherited the first imposition of an income tax from the previous administration of William Pitt, and who, during the brief period of peace with France following the Treaty of Amiens, was ready to withdraw it. Addington had appeared in a number of political caricatures prior to this, the earliest in 1793, nine years previously, but this is the first print in which he appears in the role of a physician. It represents an important beginning, for before he retired from public life in 1824, Addington, later Lord Sidmouth, had been cast in the role of doctor, apothecary, quack, nurse, or pharmacist in more than 130 political prints. Such a record deserves recognition. James Gillray, the most influential and biting of all the caricaturists at work at the beginning of the nineteenth century, used the same medical theme a year later in Doctor Sangrado curing John Bull of repletion (BM 9986, plate 2). The print is a parody on the physician Dr Sangrado in the popular French romance by Le Sage, Gil Blas. Addington is again the doctor bleeding John Bull, who sits on a commode labelled "Reservoir for the Clysterpipe family!". The print has a double purpose-to protest the level of taxes necessary to support the war with France that had temporarily been halted and to comment on the lucrative sinecure Addington had obtained for his then sixteen-year-old son, to which the words "Clysterpipe family" refer. Both of these prints relate to taxation, for the theme of John Bull being treated, and particularly bled, by physicians is one of two classic formulas for such events, the other being John Bull crushed under the burden. ${ }^{3}$

Addington also appeared in an 1804 print by James Gillray in which an earlier symbol of the nation, Britannia, was treated by doctors. Britannia between death and the doctor's (BM 10,244, plate 3) celebrated Addington's rather ignominious retirement from office and his replacement by William Pitt, the political leader whom he, in turn, had succeeded three years earlier. In the print, Pitt, holding high his "Constitutional Restorative", not only boots Addington out the door, his "Composing Draft" having proven useless, but also stamps on his long-term political rival, Charles James Fox, whose "Whig Pills" and "Republican Balsam" are not to be employed. As with most Gillray caricatures, there is much more to be studied, but the medical metaphor is obvious. Britannia had been treated by her doctors in prints long before John Bull, and there are several examples from the eighteenth century. ${ }^{4}$

\footnotetext{
${ }^{2}$ W.H. Helfand, 'John Bull and his doctors', Veröffentlichungen der Internationalen Gesellschaft für Geschichte der Pharmazie, 1966, 28: 131.

${ }^{3}$ George, op. cit., note 1 above, vol. 2, p. 14.

4 For example, $A$ new administration, or the state quacks administering (BM 6201) commemorates the coalition of Fox and North in forming their government in 1783. Earlier caricatures such as The Cramers or political quacks (BM 3923) and Dr Musgrave prescribing for Britannia (BM 4307) make the same point. So also does America in distress, a 1775 print by Paul Revere copied from a print in the Oxford Magazine earlier in the same year (BM 4368), substituting, for obvious reasons, America for Britannia. Similar prints can be found for France, Italy, and other nations.
} 


\title{
Medicine and pharmacy in British political prints
}

Indeed, Gillray had used a similar theme in the previous year in his print Physical aid-or Britannia recover'd from a trance... (BM 9972). In this case, the print reflects continuing dissatisfaction with the weakness and vacillation of Addington in the face of Napoleonic provocations, the theme of several prints reflecting the inertia which eventually led to Addington's fall. Britannia is supported by Addington, who holds a bottle of "Gunpowder" to her nose, and by Hawkesbury, then Foreign Secretary. The print was one of the early efforts to warn England of the possibilities of an invasion, and in it the French fleet, led by Napoleon, can be seen approaching.

A second common medical theme is the enema syringe or clyster. Its message, like that of administering medicine to a nation, is quickly grasped. Normally, it is the French who have been associated with this instrument and there are hundreds of such examples. In the hands of important French artists such as Daumier, Travies, or Cham, the ubiquitous clyster became a highly charged symbol, one normally used to represent attitudes toward those in authority. ${ }^{5}$

In British caricature, Addington is the pre-eminent individual to be associated with the clyster, a somewhat dubious claim to later fame. He is several times referred to as Dr Clysterpipe in caricatures, among related appellations. As a public figure, first as a member of Parliament, then Speaker of the House of Commons, later Prime Minister, and finally Home Secretary, it was only natural that he should appear in political caricature with some frequency. When he took office as Prime Minister, artists searched for some characterization with which he could be associated so that he could be easily recognized, similar to the bulldog image of Winston Churchill or the unshaven portrayal of Charles James Fox. But Addington had no distinguishing characteristic. By nature, he was bland, unassuming, reticent. There was nothing there to be used. In desperation, the artists seized on the fact that his father, Anthony Addington, was a doctor, then regarded as a middle-class occupation somewhat inferior to the level among members of Parliament at the beginning of the nineteenth century. As one of his biographers put it,

\begin{abstract}
...for a Prime Minister to be a doctor's son was considered not only socially distressing but irrepressibly comical as well. Much of the fault, or perhaps credit for this lay with Addington himself. Instead of prudently concealing his origins he took pride in his father's prowess and aired his own smattering of medical knowledge whenever an opportunity arose .... The wits of the age found exquisitely ridiculous Addington's pride in this achievement. The nickname of "The Doctor" was now coined. It stuck to him for the rest of his life and the constant ridicule which the concept provoked did much to destroy his reputation as a serious statesman. Some politicians can survive ridicule, others even thrive on it, but Addington lacked either the wit to reply in kind or the stoicism to suffer in silence. So "The Doctor" with flowing coat-tails and clyster-pipe sticking from his pocket, became more and more the cartoonists' butt and so the sniggers of fashionable society gradually rippled out throughout the country until the idea that the Prime Minister was at least faintly ridiculous became common currency at every level of society. ${ }^{6}$
\end{abstract}

\footnotetext{
${ }^{5}$ The earliest of the French prints date from the period of the Revolution, for political caricature directed against the state had been forbidden by Louis XVI and his predecessors. However, the French have had no monopoly on the use of the enema syringe in caricature; a number of British examples are recorded before 1789. For instance, The political clyster (BM 3557), an engraving by William Hogarth, is the second state of a print that had been first published in 1726 during the reign of George I. In a 1757 modification, the illustration of Gulliver and the Lilliputians was put to a political purpose in attacking two prominent public figures, Lord Hardwicke and the Duke of Newcastle.

${ }^{6}$ Philip Ziegler, A life of Henry Addington, 1st Viscount Sidmouth, London, Collins, 1965, p. 111.
} 


\section{W. H. Helfand}

The clyster became the symbol of "The Doctor". In more than half of the medical prints in which Sidmouth appears, he carries it as his badge of office. It even becomes part of him in a few prints, such as The Doctor-a dejection (BM 14,164), where his head is attached to it in a way that represents the ultimate association. This fanciful illustration appears as one of twenty-four woodcuts by George Cruikshank in one of the numerous pamphlets published around 1820 by William Hone, The political showman at home (BM 14,148). There is a text to each, no part of which is too flattering. In Sidmouth's case it begins with a parody from Shakespeare, "I do remember an Apothecary-A Three-Inch Fool... inflated and astrut with self conceit", and continues just as viciously. At times, as in Coronation (BM 13,803), a print from another of Hone's satirical pamphlets also illustrated by George Cruikshank, he plays his clyster as though it were a musical instrument. Some years later, in the series of Musiciens de la Chapelle, published in Le Charivari in Paris, Travies did a similar treatment of Marshal Lobau, resulting from his association with the clyster as an apothecary's instrument. In $A$ bottle of smoak or a song of sixpence (BM 13,849), a crudely drawn caricature by Maxwell, Sidmouth uses the syringe as an inhalant to revive himself, and in Consternation (BM 13,799), another Cruikshank woodcut, he uses it to revive George IV.

Clysters in British caricatures are of two types, the long solid instrument of pewter and the soft bag with a short pipe. Although the latter is much the older, it is much more frequently used in connexion with Sidmouth in the prints. It has a long history,

From Graeco-Roman times through to the seventeenth century the clyster (or enema) apparatus consisted of an ivory, bone or metal pipe to which a bag or bladder containing the medicament was attached. Either by gravity or by squeezing the bladder a flow of liquid was created.... When the pewter syringe made its appearance in the eighteenth century it quickly took the place of the bladder and pipe.?

In 1808, Charles Williams published an elaborate print showing The constitutional squad (i.e. opposition) advancing to attack (BM 10,977). As a member of this opposition in Parliament at the time, Sidmouth is a prominent member of the procession, carrying his ubiquitous long weapon over his shoulder; he also holds a basket full of bottles labelled "Pills Potions Lotions for Blundering Ministers". In caricatures, Sidmouth frequently uses the enema syringe as a weapon for attacking his enemies, a good example being Gillray's Confederated coalition... (BM 10,240), a print showing the many factions arrayed against him in 1804 at the moment he was preparing to step down as leader of the government. Here the liquid jetting from his clyster is symbolically directed at Fox, whose blunderbuss, in turn, is aimed directly at Sidmouth and hits him in the eye.

But in the body of medical political prints the clyster is shown merely to identify its bearer and to indicate the low esteem in which he is held. It is little more than an emblem. Often, it sits in Sidmouth's pocket, is held limply in his hand, or is sometimes on the floor near him. He is shown using it on occasion as in A touch of the sublime (BM 13,868) or in Figures in a fog. He holds a "Royal Clyster" in Rumping an illustrious personnage as he offers to prescribe for the king. In more than one case,

${ }^{7}$ Leslie G. Matthews, Antiques of the pharmacy, part II, Hounslow, Merrell Pharmaceuticals, 1984, p. 15 . 


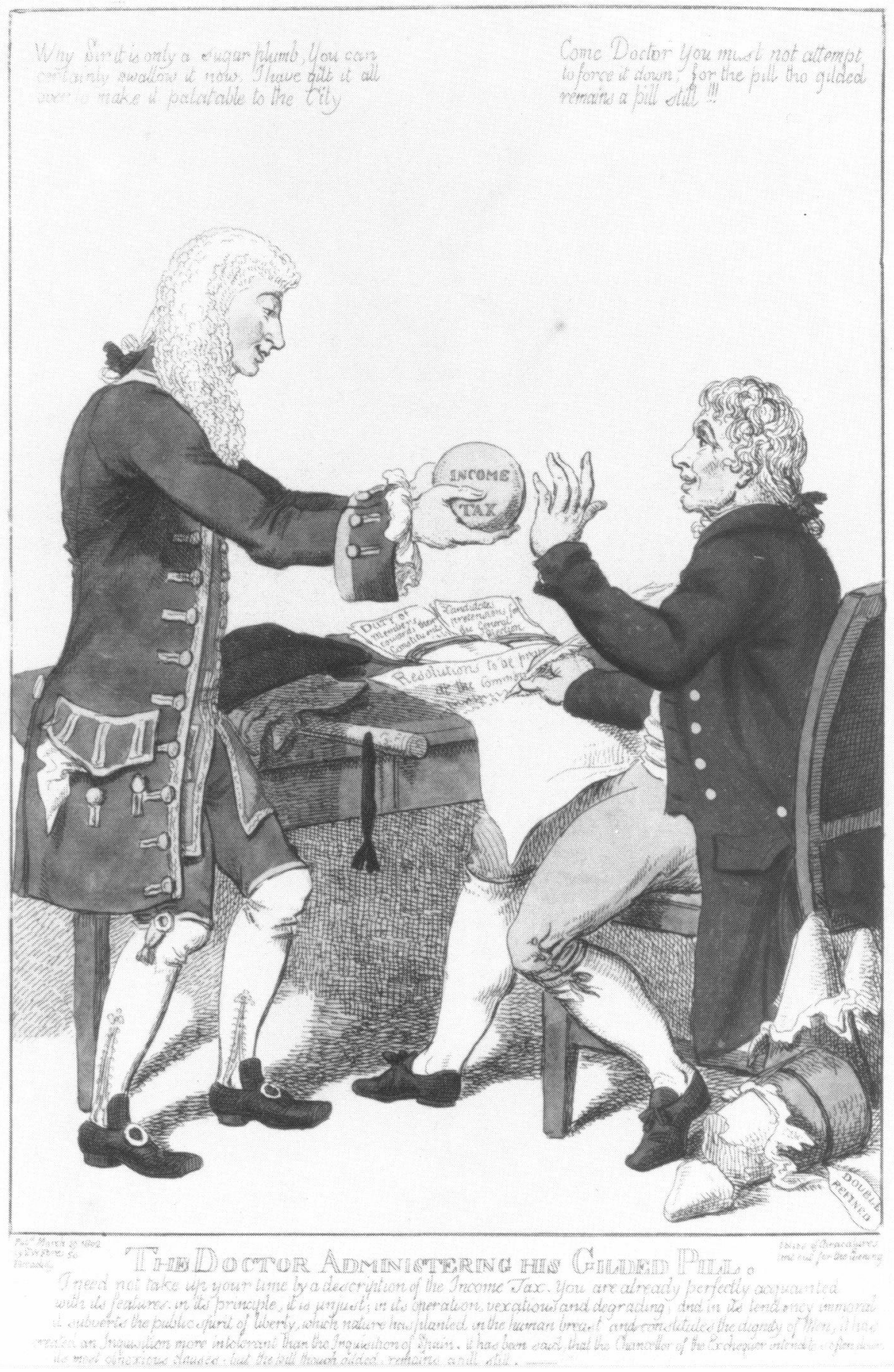

Plate 1. The doctor administering his gilded pill. Coloured etching, attributed to C. Williams, London, 1802. (British Museum, Catalogue of ... satires no. 9849.) 


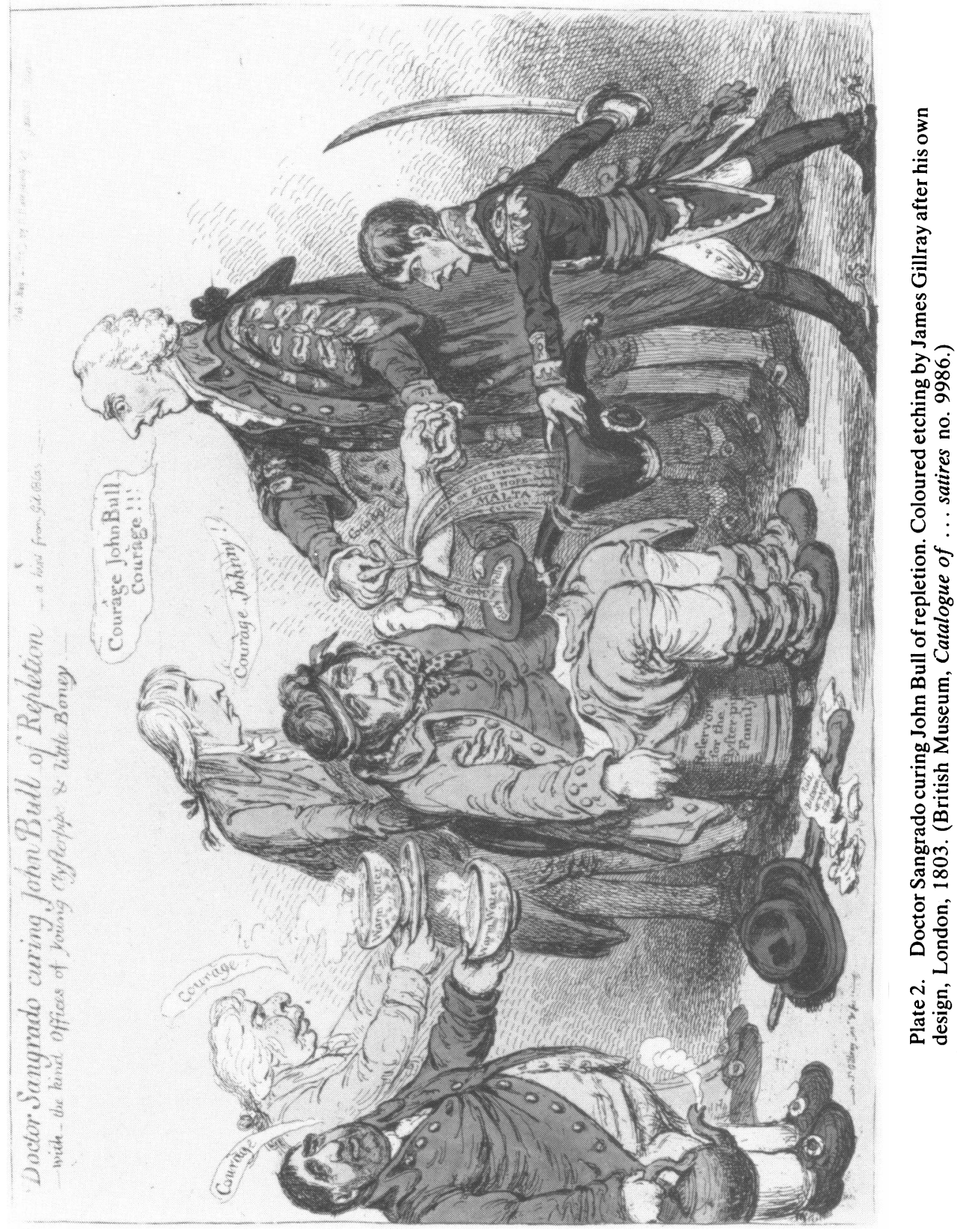




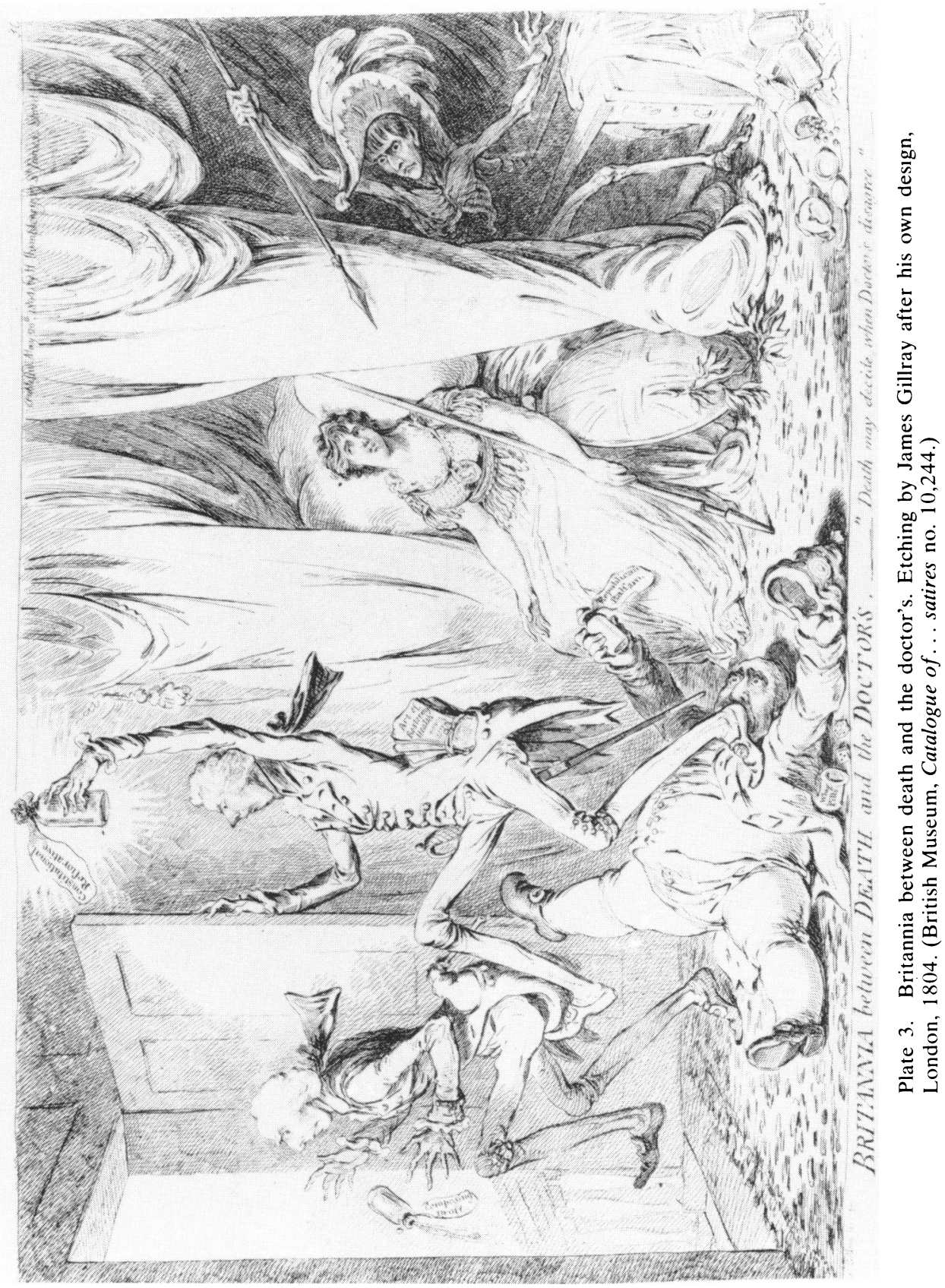




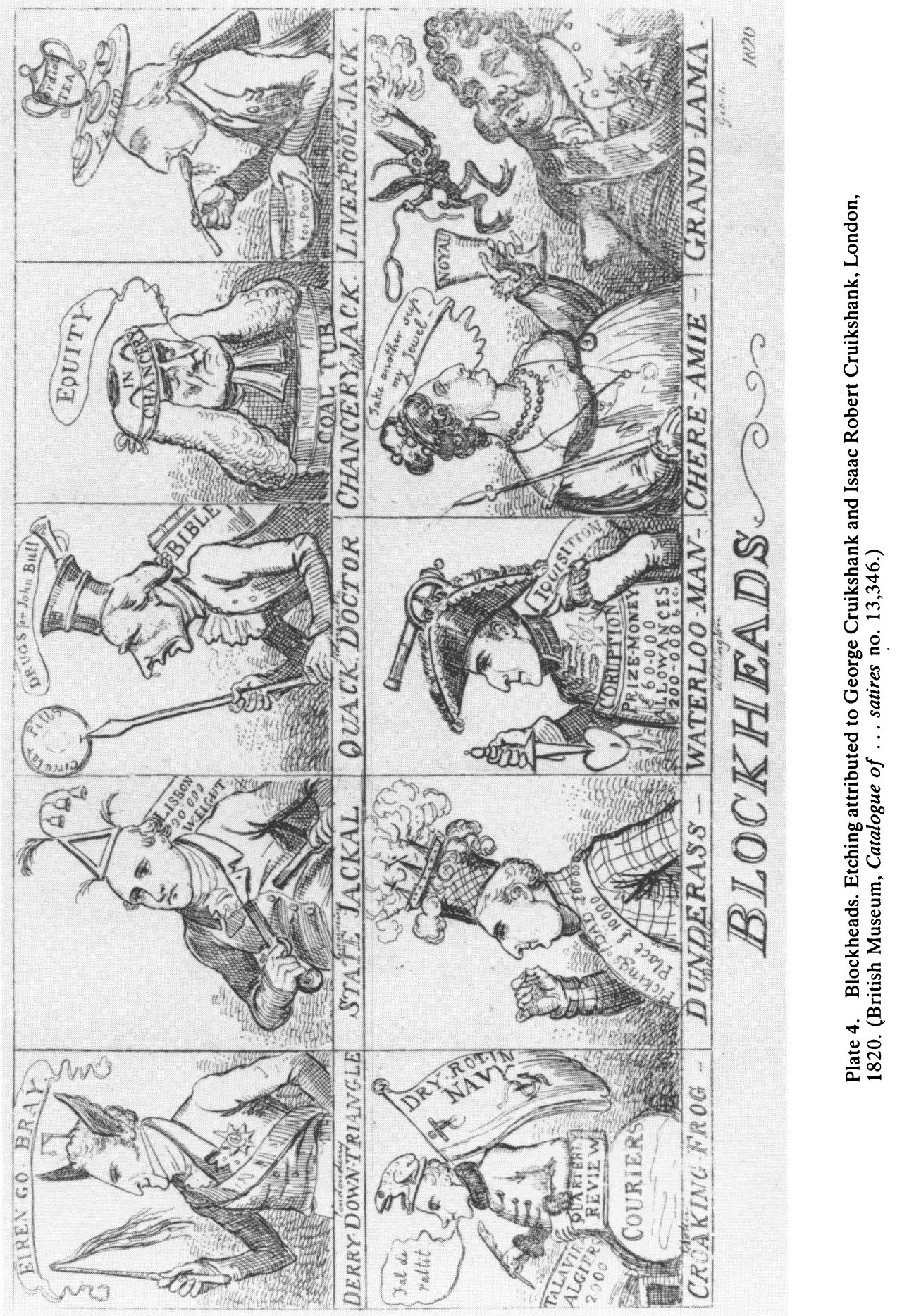




\section{"THE DOCTOR"}

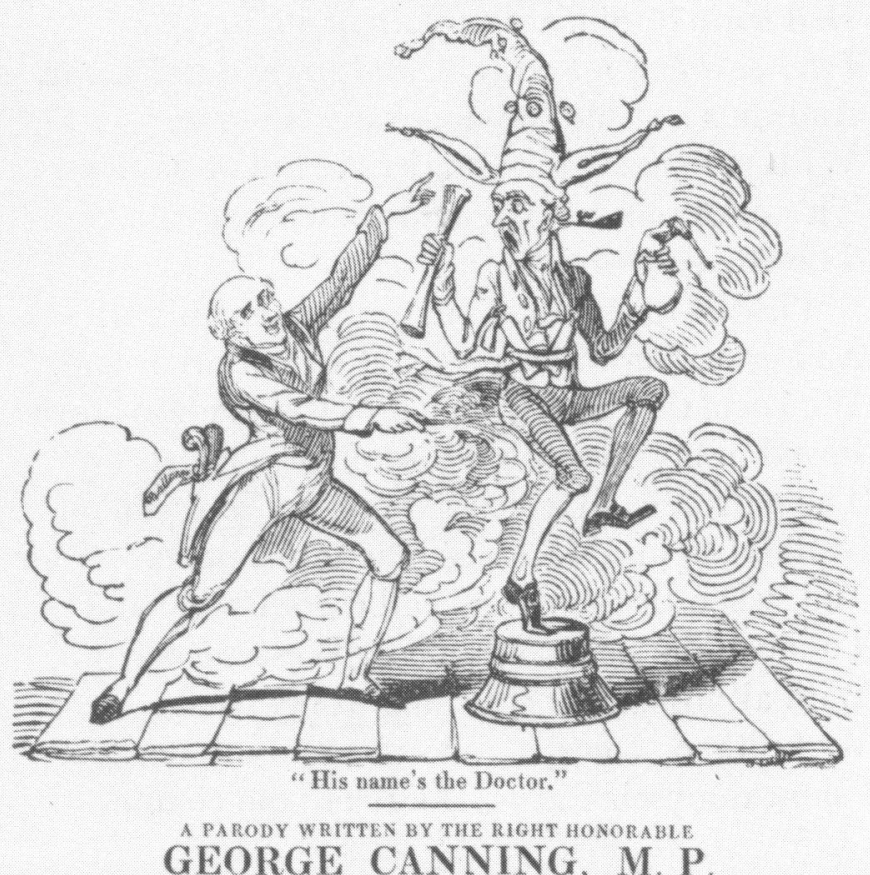

Lord FOTKRSTON Econfessed that there had been a swile on his cowntenance at one part of the right honorable gentleman (Ur. CAN NING)'s speech, and it seemed to him very extraurdinary, even after the reconciliation that had taken place, to hear the right honorable gentleman stand up for the talents of hat poor "Doetor" (Iord S I DMOUTH), who bas solong

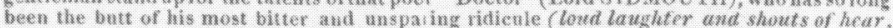
hear). Whether in poetry or prose, the great object of his derision, and that for want of ability

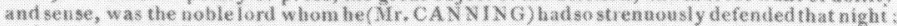
hands of a person, according $t 0$ his owa furmer opinions, so likely to be duped and misted hads of a person, according to his owa furmer opmions, so hisely to be doped and misied
(heor, hear). Yes, the honse would remember the lines in which, at difterent times, the right honorable gentleman (Mr. CA N I NG), had been pleased to panegy rize his (Mr. CA N N I G's) noble friend (Lord SID MOU $\mathrm{FII}$ ) of which the following were aut the sorst:-

"I showed myself prime Doctor to the conntry;
My end" attinin'd, my only aim bas been

Tokcep my place, and gild my humble name."

Yes, this was the view the right honorable gentheman had once drawn of bis woble friead, who was thert deseribed by him thus:-

"My name's the Doctor-n the Berkshire hills," \&

[See the Parody brine for the remainder of Lend Fulkestone*s

Quotalim- For his limdship's Speceh, see Evans's Dehates, 1817, p. 1ses.)

My name's THE DOCTOR ; on the Berkshire hills

My father purged his patients-a wise man,

Whose constant care was to increase his store,

And keep his eldest son-myself-at home.

But $I$ had heard of Politics, and long'd

To sit within the Commons' House, and get

$A$ place, and luck gave what my sire denied.

Plate 5. "The doctor". Woodcut by George Cruikshank from The man in the moon, London, W. Hone, 1820. (British Museum, Catalogue of ... satires no. 13,520.) 


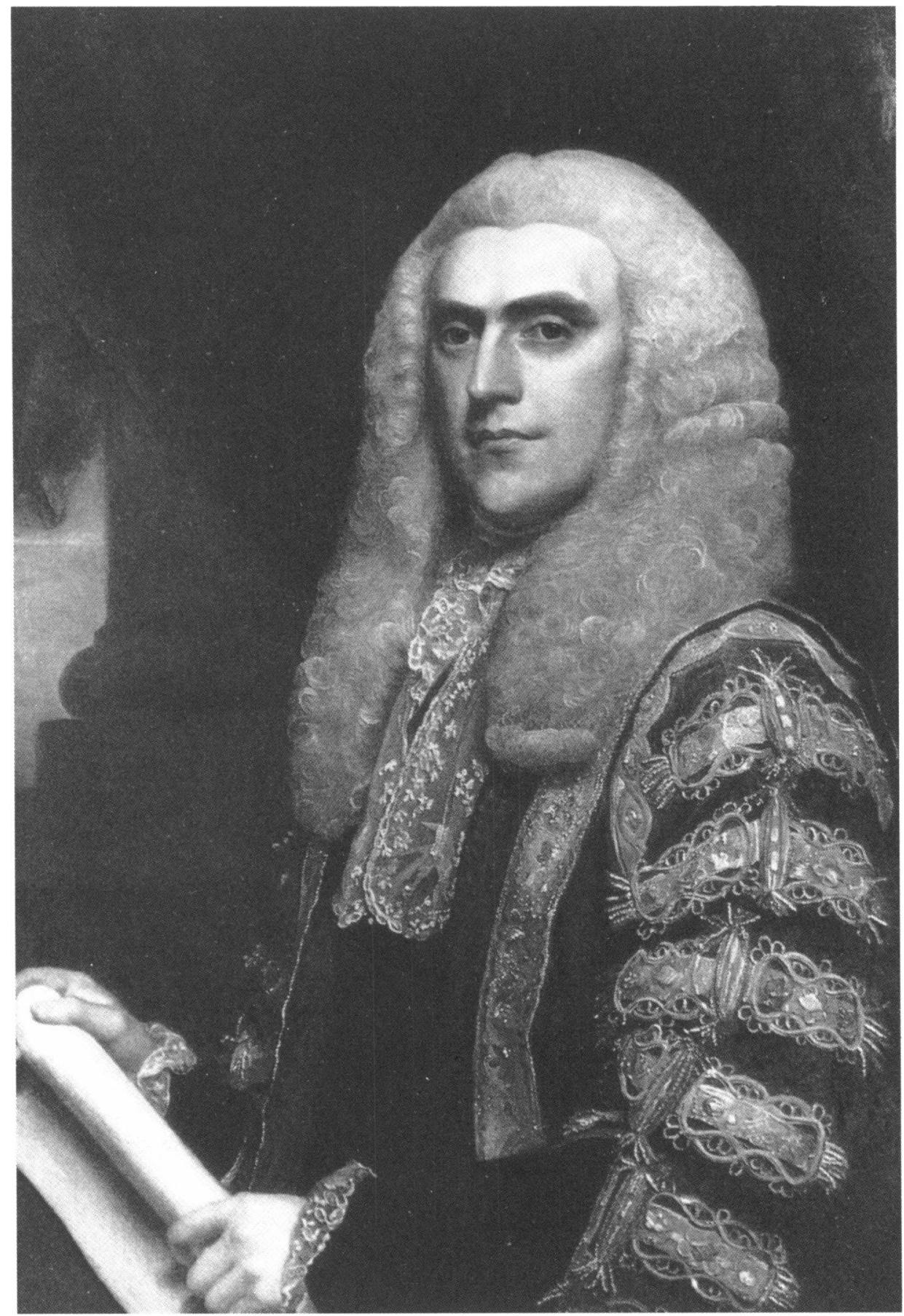

Plate 6. Portrait of Henry Addington, 1st Viscount Sidmouth. Oil-painting by John Singleton Copley. City Art Museum, St Louis, Missouri. 


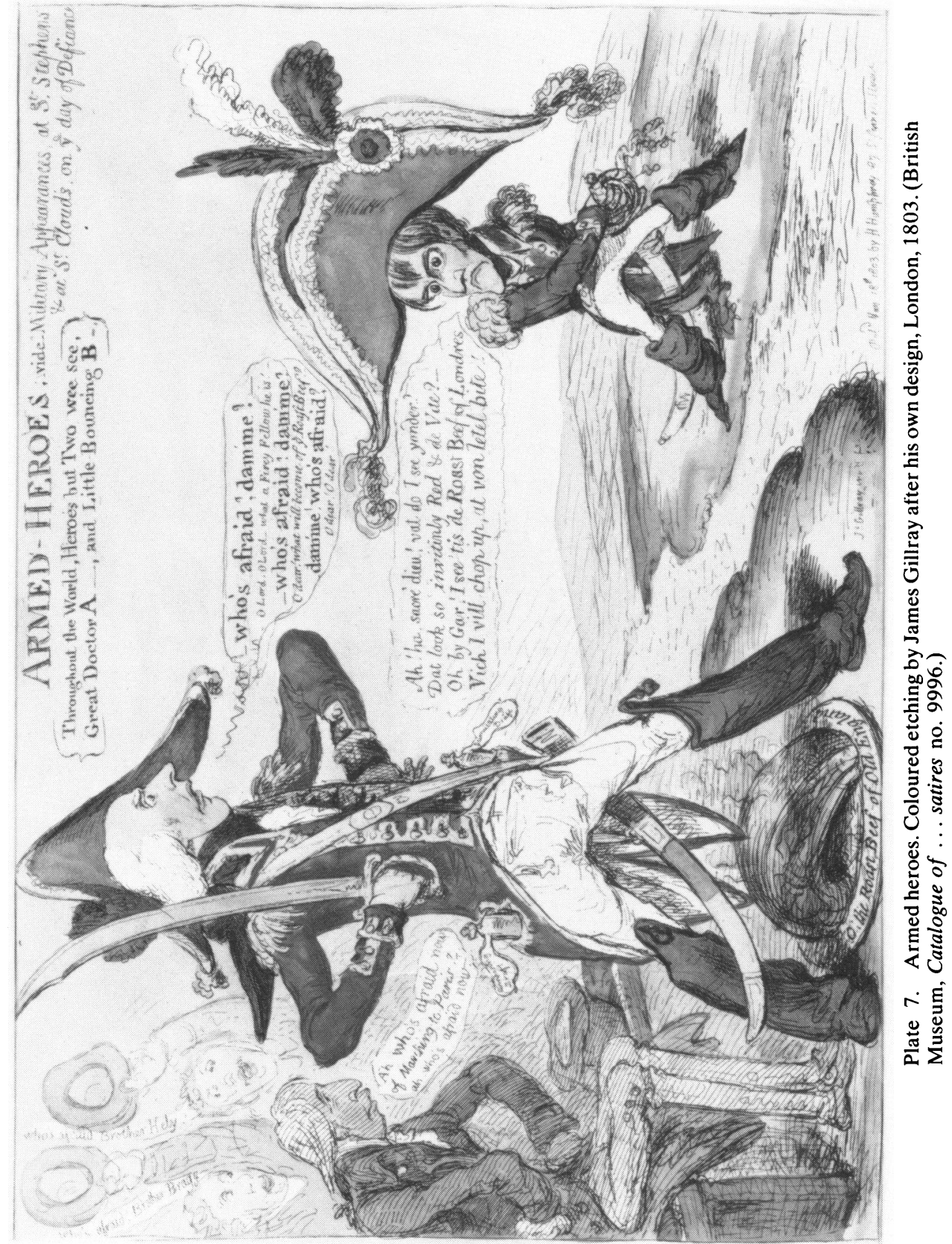




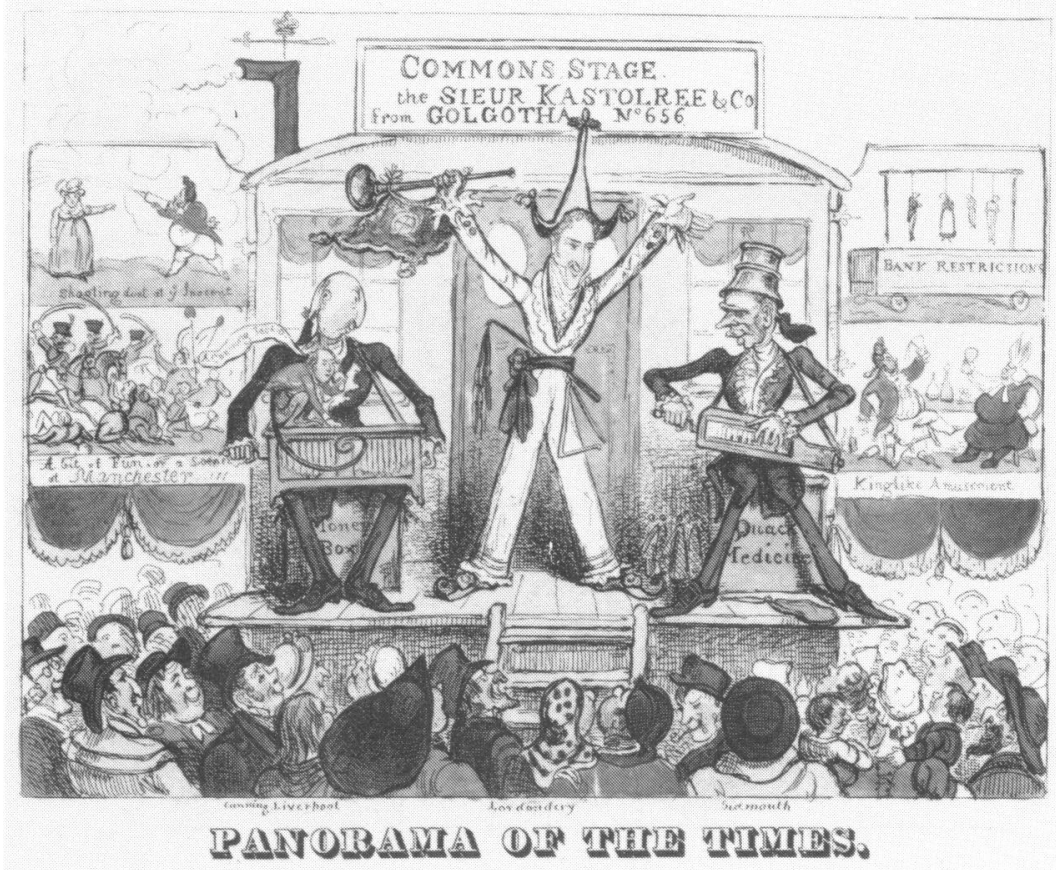

THE SIEUR KASTLEREE,

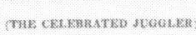

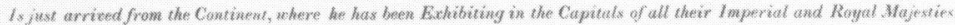
the Socereigns of liuropes.

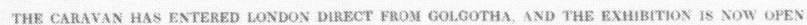
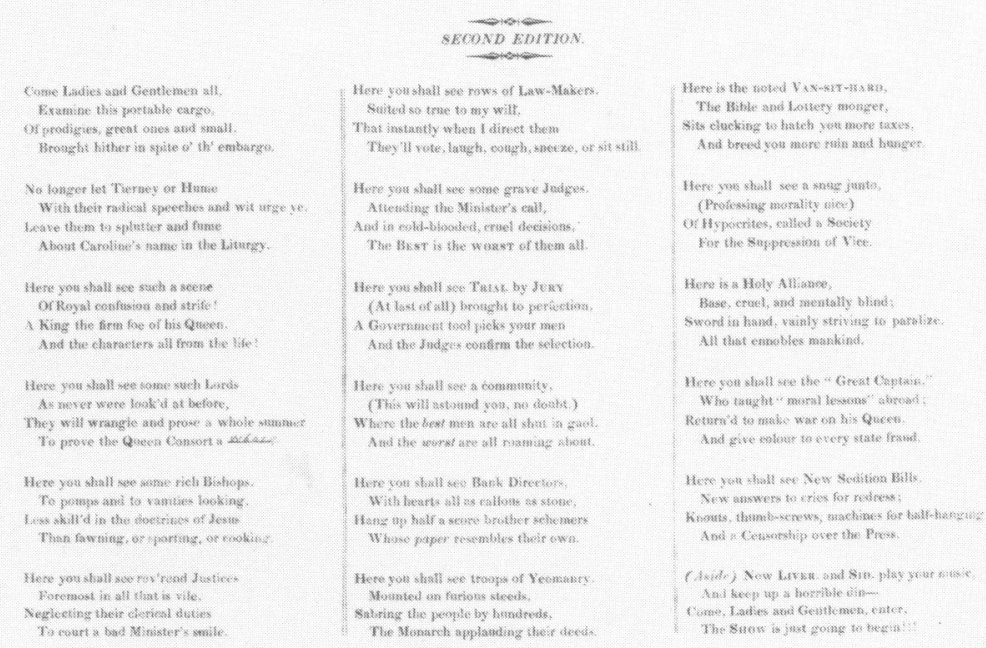

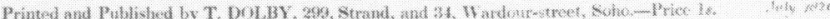

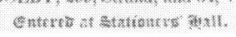

Plate 8. Panorama of the times. Coloured etching with text, London, T. Dolby, 1820. (Collection of William Helfand.) 


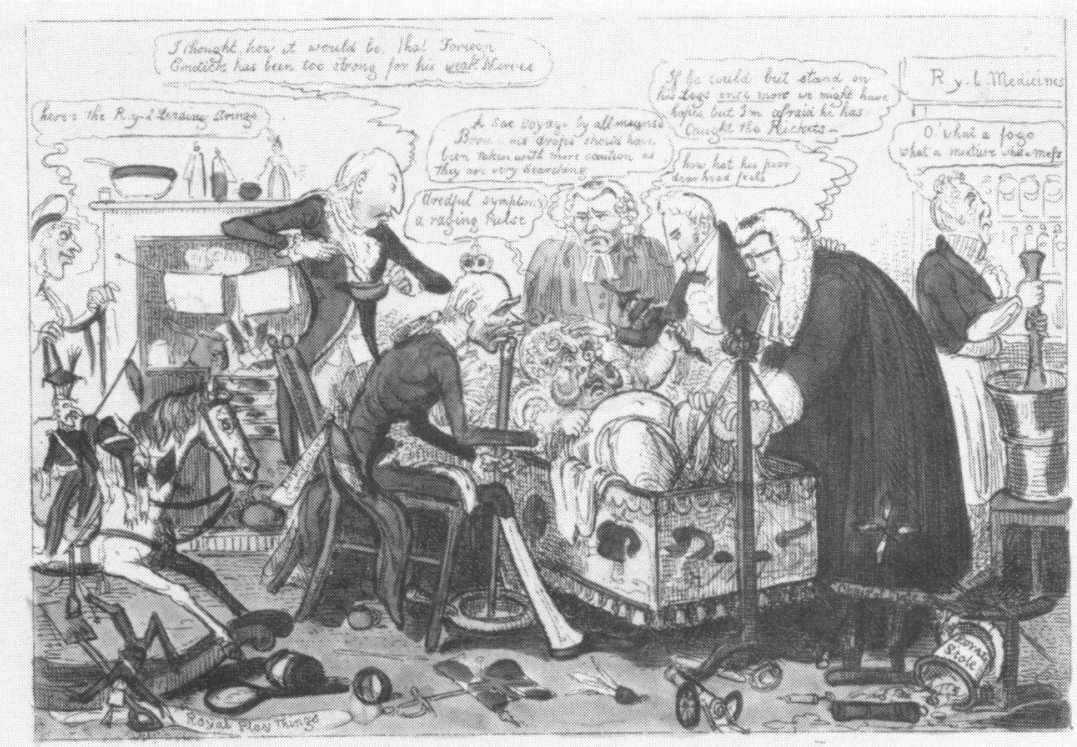

\section{THE ROYAL COT,}

\section{The Great Babe taken III. \\ $\triangle 1 . C O N D$ EDITION}

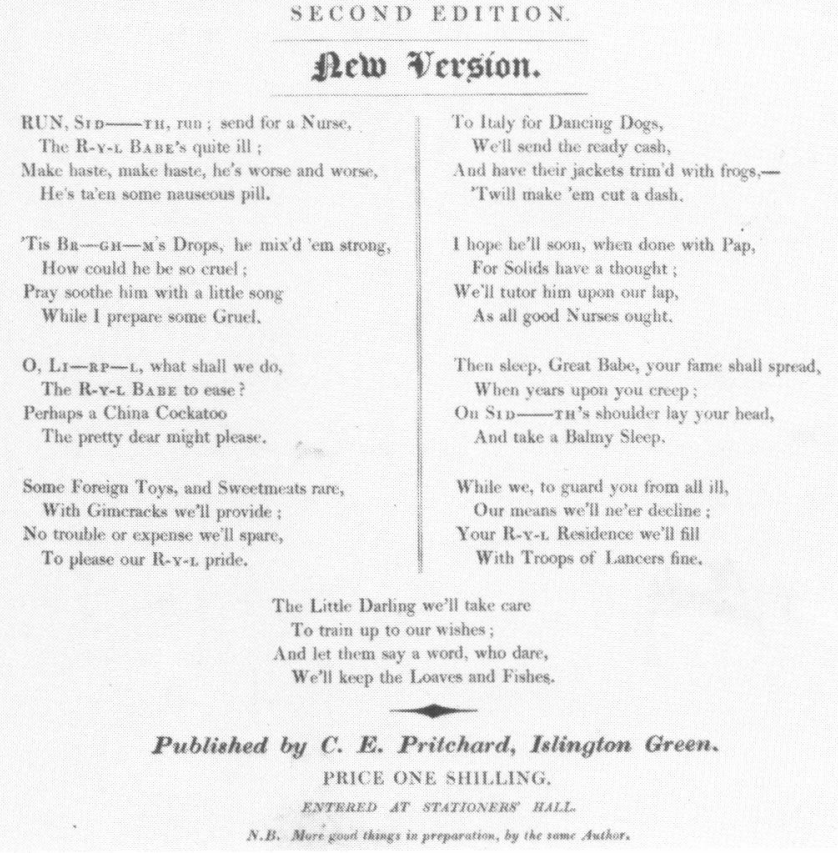

Plate 9. The royal cot. Coloured etching attributed to Isaac Robert Cruikshank, with text, London, C.E. Pritchard, n.d. [1820]. (British Museum, Catalogue of ... satires no. 13,843.) 


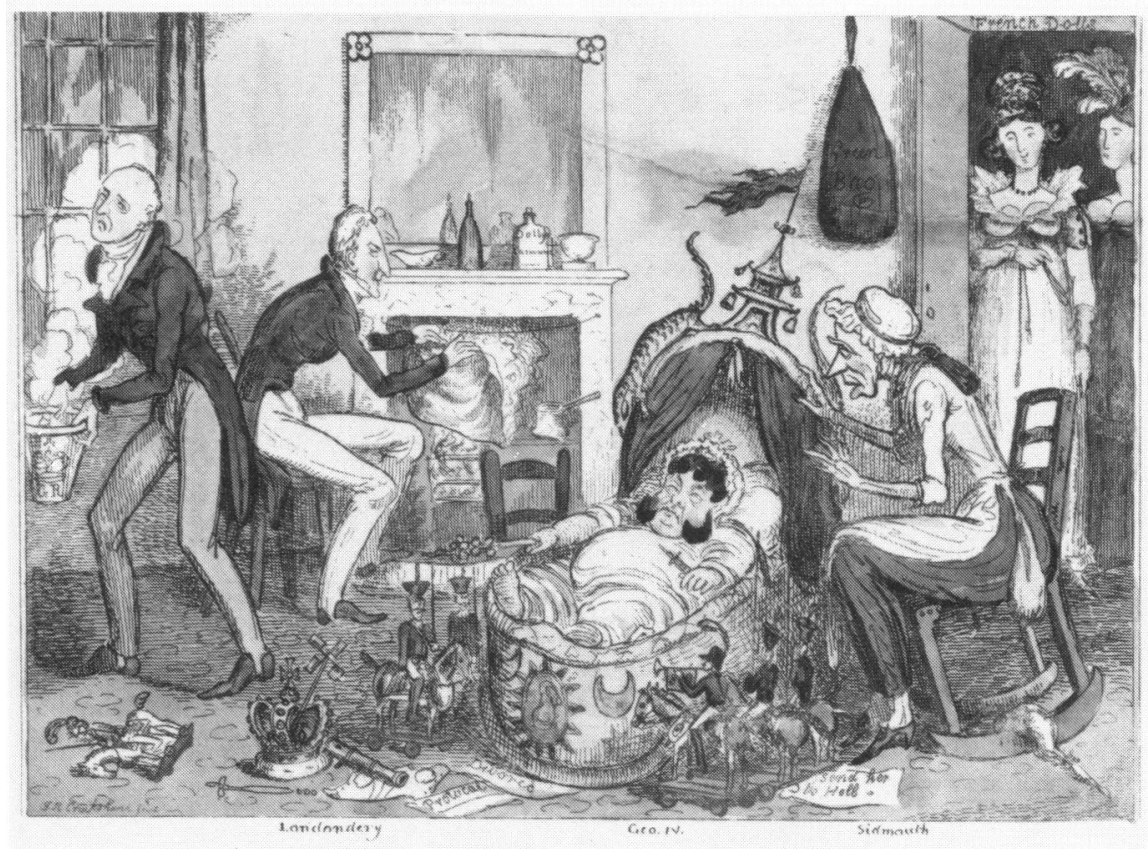

\section{TEET OBADLE FYIIIN。}

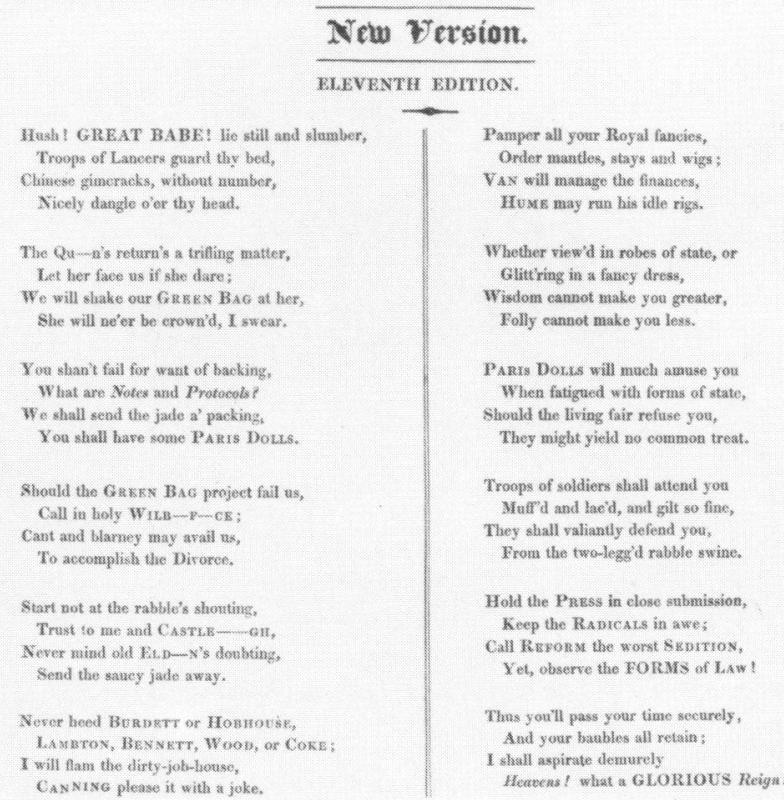

Plate 10. The cradle hymn. Coloured etching by Isaac Robert Cruikshank with text, London, 1820. (British Museum, Catalogue of ... satires no. 13,764.) 


\section{Medicine and pharmacy in British political prints}

the instrument is shown without him, and the viewer was somehow expected to know to whom the image refers. This was certainly quite clear during the period 1820-21 when Sidmouth, as Home Secretary, was deeply involved in the proposed divorce proceedings of George IV. From this, nearly eight hundred political caricatures survive. ${ }^{8}$ The issue of queen versus king and king versus queen was eminently suited to the uninhibited caricature of the day. Almost, but not quite all, are anti-George IV and anti-government; Sidmouth, as one object of hatred, among others, is continually, often violently, under attack. ${ }^{9}$

In the events which unfolded during the lengthy proceedings, Sir John Leach, the Vice-Chancellor in 1818, formed a Milan Commission (BM 13,763), charged with the responsibility to go to the continent to obtain whatever evidence it could against Queen Caroline, concerning her behaviour during her years of separation from the king. That separation had been a long one, having commenced almost at the beginning of their marriage. Typically, Leach himself became a convenient target for the caricaturists, who easily invented an appropriate iconological symbol for him. Sidmouth and his clyster appear in several prints commenting on the Milan Commission, The master cook... (BM 13,755) and The Milan garland... (BM 13,760) among them. In the centre of this latter print is a large green bag into which was to be placed all the evidence obtained by the Commission. On the day after Caroline arrived in England for her trial, several such green bags of paper containing the evidence to be used against her were given to Parliament. Such a symbol was too convenient not to be used repeatedly by the caricaturists, and it and Sidmouth, among others, appear frequently. ${ }^{10}$ The Arrival of the wretches (BM 13,758) commemorates the arrival of several witnesses to testify against the queen in her trial, still another excuse for a blow against the king and his demands. In this instance, a number of Italians, some of whom had been in the queen's service, had been brought over by the government, in the expectation that their evidence would tell against the queen. It was widely believed that they had been bribed. ${ }^{11}$ The Bill that was presented to Parliament for the divorce was also an excuse for caricature. This proposed act, in the form of a Bill of Pains and Penalties, was specifically referred to in $A$ New Year's gift to a $K$--g, Queen Caroline running down the Royal George (BM 13,900) and The green bag hobby to frighten the innocent (BM 13,985), to name but a few of those in which Sidmouth and his clyster are present.

When drawn as a doctor, there were several other possible symbols for Sidmouth, for example, mortars and pestles. Sidmouth stands on a mortar in a print by Isaac Robert Cruikshank, George's brother, $A$ peep into Cotton Yard aviary (BM 13,903), as he empties the contents of a green bag (again). The print is a heading to a broadside containing eight verses which offer adverse comments on

\footnotetext{
8 John Wardroper, Kings, lords, and wicked libellers. Satire and protest 1760-1837, London, Murray, 1973 , p. 213.

${ }^{9}$ George, op. cit., note 1 above, vol. 2, p. 187.

${ }^{10}$ Examples included Magic-the green bag metamorphosed or the moutain in labour (BM 13,739); Caroline's wooden broom to sweep the filthy committee room; and Doctors, bishops, judges, generals, and statesmen at hard work, or a sitting committee.

${ }^{11}$ Edgell Rickwood, Radical squibs and loyal ripostes. Satirical pamphlets 1819-21, Bath, Adams \& Dart, 1971, p. 315.
} 


\section{W. H. Helfand}

each individual in the scene. He does the same in a print on excessive military spending. Consultation on the best cure for the gout ... (BM 12,805), published in 1816 at the conclusion of the war with France. Here Sidmouth, as a physician, is examining the immensly enlarged hand of a gouty George IV, as he notes "Oh Derry do come and look. We must supply some speedy remedy for the infection is spreading fast!!" In another caricature by I.R. Cruikshank, An heirogliphic adapted to these wonderful times ... (BM 13,984), he actually uses a mortar and pestle while sitting on the omnipresent green bag. In several prints he is made to look rather ridiculous in wearing a mortar as though it were a hat. Blockheads (BM 13,346, plate 4), by the Cruikshank brothers, is a good example. Here the mortar contains "Drugs for John Bull", and the bolus on Sidmouth's pike is labelled "Circular Pills", an allusion to a request Sidmouth had made earlier. In July 1819 , as Home Secretary, he had sent a circular to the Lord-Lieutenants, his representatives, in all those counties in England in which there had recently been political disturbances, calling on them to adopt all measures necessary for the preservation of order, to place themselves in communication with the magistrates, and to keep the yeomanry in readiness. ${ }^{12}$ They were given permission to arrest anyone for selling anything they considered seditious or blasphemous. The cartoonists, then as now more often on the reformer's side, immediately dubbed him "Doctor Circular" or "Old Circular". The name stuck and it appears in a number of subsequent prints. In State caterpillars, Doctor Circular is one of eighteen figures singled out as "Members of the Plot Club", and in a verse similar to what would appear on comic valentines somewhat later, he is attacked directly:

\footnotetext{
Poor tottering wretch, whose calf has fled

His leg, to centre in his head;

Who left the potion and the pill,

As pander to the royal will;

Who left the drugs for sake of pelf

And has become a drug himself.
}

The circular tag is also used in the words Sidmouth proclaims while flying through the air in A kick up in a great house, "The d_d Bull has given my poor Brain such a Circular Twist-I fear all the Pills Clysters Emetic, Draughts, and Bolus's in my shop-will never put right again". And, in William Hone's highly successful political pamphlet of 1819, The political house that Jack built (BM 13,292), George Cruikshank shows Sidmouth, Viscount Castlereagh, and George Canning together in a small woodcut, The doctor (BM 13,301), which begins,

This is The Doctor of Circular Fame

A Driv'ller, A Bigot, a Knave without shame....

In The Man in the Moon (BM 13,508), an 1820 satire also published by William Hone, there is one poem addressed to Sidmouth, The doctor (BM 13,520, plate 5). In the illustration at the beginning of it, George Cruikshank shows Sidmouth not only

\footnotetext{
12 M.D. George, Catalogue of political and personal satires preserved in the Department of Prints and Drawings in the British Museum, vol. 9, London, 1949, p. 938.
} 


\section{Medicine and pharmacy in British political prints}

with a mortar and a clyster, but, remarkably, a stethoscope as well. When one considers that Laënnec's Traite de l'auscultation mediate had appeared only in the prior year, it is a remarkably rapid communication, and the illustration probably represents the first appearance of a stethoscope in any political caricature. The text is purportedly written by George Canning, for many years Sidmouth's chief critic, but, at the time of the publication, a colleague of his in the Tory cabinet of Lord Liverpool. Hone, the successful author of a number of radical pamphlets critical of the behaviour of George IV and the system which made such behaviour possible, refers to this in his introduction to the pamphlet, which is "dedicated to the Right Hon. George Canning ... who after lampooning Lord Sidmouth, and holding him up to the scorn and contempt of all England, as a charlatan and 'Prime Doctor to the Country', now takes a subordinate part under him as a 'Prime Minister"'. In the text the words, supposedly spoken by Sidmouth, cover his career up to the time he became Prime Minister, and are not very far from the actual facts:

\footnotetext{
My name's The Doctor; on the Berkshire Hills

My father purged his patients-a wise man

Whose constant care was to increase his store,

And keep his eldest son-myself-at home.

But I had heard of Politics, and long'd

To sit within the Commons' House, and get

A Place, and luck gave what my sire denied.
}

Some thirteen years ago, or ere my fingers

Had learn'd to mix a potion, or to bleed,

I flatter'd Pitt: I cring'd, and sneak'd and fawn'd

And thus became the Speaker....

The tailpiece (BM 13,521) shows Canning and Sidmouth embracing with the symbols of Sidmouth broken on the floor, lamenting that "Brother, brother, we are both in the wrong".

Hone's verse covers the essential elements of Sidmouth's career. Addington (1757-1844) had known Pitt from his youth, and first entered Parliament in 1784 as one of his silent, steady, and devoted supporters. This loyalty brought quick rewards, and in 1789, he was named Speaker of the House of Commons, a position which demanded relatively little in the way of serious innovative activity. John Singleton Copley painted his portrait during this period, and it shows a sharp-featured serious young man, not unlike several of the Gillray caricatures of few years later (plate 6). George III liked him, and when Pitt pressed his proposals for Catholic Emancipation too far, the king replaced him with Addington. When he took office in March 1801, many of Pitt's supporters, led by George Canning, refused to join his cabinet, anticipating that his dull and mediocre leadership would quickly lead to its demise. Addington became associated with peace and plenty because of his efforts in establishing the Peace of Amiens, but, other than his conceiving of some sensible reforms in the Income Tax laws, he contributed little during the three years he remained in office. He had no outstandingly brilliant qualities and his mediocrity offered opportunity for continual sniping attacks by his political adversaries. Pitt, upon replacing him in 1804, made him Lord President of the Council one year later, and he held a number of other high offices, culminating in his appointment as Home 


\section{W. H. Helfand}

Secretary in 1813. He held this key post for ten momentous years, including the periods of the Peterloo Massacre and the Queen's Affair. $\mathrm{He}$ was an arch-conservative Home Secretary, unyielding in his desire and that of the government to maintain the status quo despite repeated provocations by opposition groups. Several prints make reference to Sidmouth's role in keeping the radicals on the defensive, a good example being Modern reformers in council (BM 13,001), an I.R. Cruikshank caricature of 1818. While the words "a challenge to Ld. Sidmouth" are minimal, the print is of interest in that it shows one of the radicals, James Watson, with a number of pharmaceutical objects.

On 19 September 1820, George IV left his pavilion at Brighton on the royal yacht to get away during a brief adjournment in the queen's trial. Any event, even one so insignificant as this, was useful to the printmakers, who appeared to be continually running out of ideas, and I.R. Cruikshank, seized upon this one to issue a print. In his A sea voyage taken by the recommendation of Doctor Sid \& Co., for the restoration of the great babes health (BM 13,853), Sidmouth is in the group, carrying a "Royal Medicine Chest" under his arm and a clyster labelled "Portable Soup". In a number of other prints, he carries or offers specific nostrums, often with fanciful names. In Armed-heroes (BM 9996, plate 7), a Gillray print published on the day Addington's government declared war on the French in May 1803, he holds in his pockets both a "Composing Draft" and a "Stimulating Draft" reflecting Gillray's, and others', views on the vacillations of the government. In The wounded lion (BM 10,421), also by Gillray, he has an emetic and some "opening pills"; in St Steven's Statute (BM 10,523), issued after Addington's resignation from the government, he holds a bottle of "Cordial Julep" which Fox seems to want, and in Kissing hands or new appointments (BM 10,526), published by Williams, in announcing the new "Ministry of All the Talents" formed at the beginning of 1806, he throws away a bottle of narcotic repeating a line from Macbeth, "Throw Physic to the Dogs I'll have none of it". He carries some "Viper Drops" in Gillray's Sketch for a monument of disappointed justice (BM 10,584), and the same "Composing Draft" he had previously in Gillray's Visiting the sick (BM 10,589), issued during Fox's fatal illness. In one of the ten designs of Williams' New London cries or all the talents making themselves useful (BM 10,726), he holds out a bottle of a "Cordial for Bad Consciences!", and he offers a "Cathartic" in Gillray's An old English gentleman pester'd by servants wanting places (BM 11,330). In this satire on weaknesses in the cabinet under the leadership of the Duke of Portland, Sidmouth, who in reality had no hopes of joining the government, is made to say, "Pray your Honour remember Doctor Slop, your old Apothecary who phsick'd the French!". And there is still more. In $A$ pair of state porters (BM 12,882) by Williams, Castlereagh and Sidmouth carry both "Effervescing Powders" and "Detonating Balls". Sidmouth has a bottle of "Strong Mixture" in his pocket in The broken crown; or, the disasters of a green-bag chief!!! (BM 14,006). In this I. R. Cruikshank caricature, the heading to a broadside of seven verses, there are other agents as well, "A Blister for the Radicals if they Kick up a Row", "A Gagging Bandage", and even a pot of "Poison for the $Q \_$_. To repair the crown, supposedly broken by the force of public opinion, the final verse suggests: 


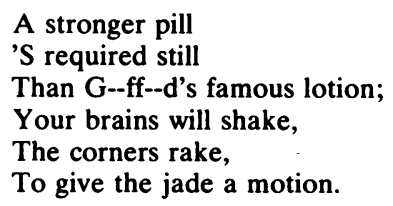

There is, finally, a print published early in Addington's administration, Pills for Paul, or English prescriptions for northern complaints. In it, there are cannon-balls labelled "Nelson's Pills", and one of Addington's assistants carries a garment inscribed "Willis's Composers", a reference to John Willis, who was treating George III because the king had refused to be treated by his father, Francis. Addington states that other remedies are not needed for "the Nelson Pills seem sufficiently to operate of themselves". ${ }^{13}$

Sidmouth is a quack doctor in a print by Williams, Iohn Bull at the fair (BM 10,717), reviewing possible cabinet changes in 1807. He and his "zany" invite the audience to come closer to see his medicines, some of which are on a table. A flag flying over his stage proclaims the presence of "the celebrated Dr. Sidmouth from High Germany", the home of many notorious quacks who toured England from the sixteenth century onwards. He is also on stage offering his "quack medicine" in Panorama of the times (plate 8), a print published in July 1820 and containing eighteen verses detailing the many issues in the queen's trial. Sidmouth and Lord Liverpool are musicians in a troupe supporting, in words reminiscent of the handbills of many quacks, "The Sieur Kastleree, the celebrated juggler" who "is just arrived from the Continent, where he has been exhibiting in the Capital of all their Imperial and Royal Majesties, the Sovereigns of Europe". He appears as a nurse several times, first in The nursery with Britannia reposing in peace (BM 9895), a protest by Gillray on the conciliation and apathy of Addington's government towards repeated aggressions of Napoleon during the peace that prevailed in 1802 , and at the failure to obtain any concessions on trade with the Continent. As is frequently the case in Gillray caricatures, minor objects convey attitudes more than words possibly could. For example, the medicines in the print include a "composing draught" and "opiate pills", and there is also a pot of "French Pap" on the floor. He is a nurse again, attending to George IV, in three prints which appeared in 1820 commenting on the queen's trial; I.R. Cruikshank's The cradle hymn (BM 13,764), the Old nursing song, and Marks' A song of Sid. All have verses, two of which in the last of the three state:

Who taught these to abuse thy Wife,

Who made up all this trying fuss

And who conspir'd to take her life-The Nurse.

Who, when the babe was taken ill,

Who procur'd each golden pill

Perjurers pockets for to fill-Thy Nurse.

${ }^{13}$ A.M. Broadley, Napoleon in caricature 1795-1821, vol. 1, London and New York, John Lane, 1911, p. 141 . 


\section{W. H. Helfand}

As a doctor in political caricatures, Sidmouth performs the usual functions. In several, he is shown taking a patient's pulse. For example, in Moments of pain (BM 13,988) and The royal cot ... (BM 13,843, plate 9), he takes the pulse of George IV, in the former depicted as an oriental potentate and in the latter again a whiskered infant, or "Great Babe" as he was often called. Both as regent and as king (George was fifty-eight years old when his father died after a long illness in January 1820), George was a sad figure, mocked for his wigs and whiskers, his gout and fatness, his drinking, gorging, fêtes, palaces, tailors, and women. ${ }^{14}$ Sidmouth's diagnosis here is "Dreadful symptons [sic] a raging pulse" and he probably would prescribe the "Dolby's Carminative" in his pocket. This same remedy was on the chimney piece in a related print, The cradle hymn (BM 13,764, plate 10), and is a paraphrase of the well-known proprietary medicine, Dalby's Carminative, the Dolby in the transcription referring to a radical bookseller of the day, and, in fact, the publisher of the print and the broadside that accompanied it. In this print, Lord Liverpool, holding a pap-boat, says, "I thought how it would be that Foreign Emetick has been too strong for his weak Nerves". There is also an apothecary mixing some of the " $R \_y \_l$ Medicines" commenting, "what a mixture what a mess" in what appears to be a pharmacy in the sick-room. Two of the verses in the broadside under the print read:

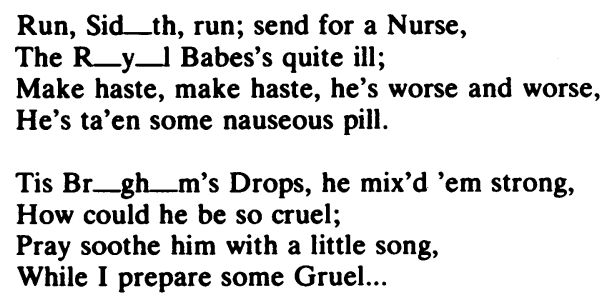

In the final medical print in which he appears, Sidmouth is again a doctor, taking the pulse of the Duke of Buckingham in one of the many comments on the various bills for parliamentary reform in the 1830s. This one, The mountain in labour (BM 16,996), was drawn by John Doyle in 1832. Sidmouth, who had left the field of active politics in 1824 and was nearly forgotten eight years later, still maintained his association with medicine in the satirical press. What better symbol to put into an illustration with a medical theme than "The Doctor". Here he replies to Buckingham's feeling of exhaustion, "After so severe a labour it is but natural-I would recommend you a composing draught, and to keep very quiet."

While Sidmouth is the doctor or apothecary in so many British caricatures, he is, of course, not the only one to be so characterized. Many important British political figures have appeared in this role over the last 200 years, but none has been so characterized so often. Sidmouth's long political career fell into the period between the caricatures of James Gillray and those of John Doyle, between the political leadership of William Pitt and the Duke of Wellington, a period that included many

${ }^{14}$ Wardroper, op. cit., note 8 above, p. 188. 


\title{
Medicine and pharmacy in British political prints
}

great names in British political life. Few political figures have had so long a history in political prints, although in the twentieth century, Winston Churchill comes close. ${ }^{15}$ In Sidmouth's case, the contrasts between the beginning and the end of his appearances in prints could not have been more dramatic. His times spanned a golden age of political caricature, perhaps less heroic a period of political advance. Gillray was part of an age of almost unlimited licence, and his savage and vicious pen recorded it, and often led it into levels of venomous attack that had rarely been seen before. Sidmouth, or Addington as he was then, was one of the many victims of these onslaughts. By the 1830s, a milder and calmer era had come, and with the beginning of Victoria's long reign the nation was ready for a less emotional approach. The caricaturists had long thrived on royal and noble misbehaviour and did not find her an inviting target. As Thackeray noted in reviewing the differences between George Cruikshank and John Doyle as examples of the changes in caricature that had taken place,

\begin{abstract}
George Cruikshank used to people [his caricatures] with grinning fantastical imps .... There used to be a crowd around the window in those days, of grinning, good natured mechanics, who spelt the songs, and spoke them out for the benefit of the company, and who received the points of humour with a general sympathysing roar. Where are these people now? You never hear any laughing at HB (John Doyle); his pictures are a great deal too genteel for that-polite points of wit, which strike one as exceedingly clever and pretty, and cause one to smile in a quiet, gentlemanlike kind of way. There must be no smiling with Cruikshank. A man who does not laugh outright is a dullard, and has no heart; even the old dandy of sixty must have laughed at his own wondrous grotesque image, as they say Louis Philippe did, who saw all the caricatures that were made of himself. ${ }^{16}$
\end{abstract}

Thackeray's image of a kindly disposed George IV and kindly disposed Louis Philippe is considerably off the mark, for these political prints were telling attacks on all the political figures of the time. He was right in the changes, however; John Doyle and the cartoonists from Punch and its imitators still produced some creative political prints, but their point of view generally bespoke a quieter age. Sidmouth would certainly have suffered less under their approach, but at the same time, we would be left with a much less memorable group of political caricatures.

\footnotetext{
${ }^{15}$ Churchill's appearance in political prints spans more than fifty years. See Fred Urquhart, W.S.C. A cartoon biography, London, Cassell, 1955.

${ }^{16}$ William M. Thackeray, 'George Cruikshank', Westminster Review, no. 66, June 1840.
} 